movitch suggested the main ideas for the further development of the 'Tokamak' systems : new methods of heating and ways of changing the magnetic configuration.

In 1930 , L. A. Artsimovitch began his teaching activities, first in the Leningrad University, later in the Moscow Physico-Engineering Institute and, from 1953, in the Lomonosov State University in Moscow. He was a brilliant lecturer who could clearly and vividly present the most complicated aspects of modern physics, and he enjoyed a well-deserved esteem and popularity among the students.

From 1944, L. A. Artsimovitch worked in the Kurchatov Atomic Energy Institute. In 1946 he was elected a corresponding member of the Academy of Sciences of the USSR, in 1953 he was elected a full member of the Academy. Since 1957, he permanently held the post of Secretary of the Department of Physics and Astronomy in the Academy of Sciences and was a Member of the Academy Presidium.

L. A. Artsimovitch was held in a high respect by Soviet and foreign scientists which was due not only to his outstanding scientific works but also to his personal qualities - his personal integrity, his profound and versatile learning, his literary and oratory brilliance, his fine sense of humour. When he delivered a scientific report, the report was always vivid and fascinating. When he presided over a conference, the conference was not protracted and invariably produced results. When he wrote a scientific monograph or a popular article, it was always exciting reading.

For his outstanding contribution to the development of science and technology, L. A. Artsimovitch was awarded the title of a Hero of Socialist Labour; he was awarded Lenin and
State Prizes and was decorated with three Orders of Lenin and two Orders of the Red Banner of Labour.

L. A. Artsimovitch was elected an honorary member of national academies of many countries.

L. A. Artsimovitch was a member of the Lenin Prize Science and Technology Committee, a member of the Commission on the Scientific Problems of Disarmament affiliated to the Presidium of the Academy of Sciences of the USSR, Chairman of the National Committee of Soviet Physicists, a member of the Executive Committee and Council of the European Physical Society, a member of the Permanent Committee of the Pugwash Conference; he took part in many important Soviet and international conferences.

National Committee of Soviet Physicists

\title{
Spring Meeting of Council
}

\section{2-23 March 1973, Sinaia, Romania}

Although there had been a state of emergency declared in Romania because of a sudden fall of $60 \mathrm{~cm}$ of snow, all the delegates to the Spring Meeting of Council in the ski resort of Sinaia arrived safely. The warm hospitality and friendly reception by the Romanian hosts more than compensated for any inconveniences that the weather imposed.

As President H. B. G. Casimir stated in his reply to the welcome by I. Ursu :

'We must thank our Romanian colleagues for putting up with a state of emergency, just so that we can enjoy the sight of fresh snow in the beautiful mountains !' Representatives from 20 different European countries had gathered for the Council meeting which was once more to prove that, despite the success of the Society's promotion of the advance of physics in Europe and neighbouring countries, there are essential weaknesses in financial support which require urgent attention.

\section{President's report}

President H. B. G. Casimir began by indicating that, after its Second EPS General Conference in Wiesbaden in October 1972, the European Physical Society should begin to look forward to the Third General Conference in 1975. He then asked the Chairmen of Advisory Committees to report.

\section{Applied Physics and Physics in Industry}

L. A. A. Thomas had formally taken over Chairmanship only on 21 March 1973 and he called upon Council to express appreciation of the activities of his predecessor, O. G. Folberth. The Committee had now completed its work to attract Associate Members (see Europhysics News, April 1973, page 5). The new Chairman saw that the two immediate tasks of the Committee were: to ensure adequate coverage of applied physics and physics in industry at Europhysics Conferences; and to organize meetings to examine how 'environmental physics' could contribute basic analyses and physical solutions to environmental problems.

\section{Conferences}

P. Radvanyi briefly described the current activities of sponsorship and approval of Europhysics Conferences, for which he invited early applications in future. He explained the need for a committee on education to scrutinize proposals for summerschools. Also, he declared the Committee's intention to survey Europhysics Conferences. Finally, a plea was put in for better representation on the Committee from the various regions of the Society.

\section{Physics and Society}

This Committee, under the Chairmanship of G. Diemer, had decided that, following two years of analysis which culminated in discussion of a working paper at the Second General Conference, action was now required. Six recommendations were to be submitted for the approval of the next meeting of the Executive Committee.

\section{Publications}

J. Depireux reported that after the work on the general physics journals in Europe, the Committee were now moving ahead with examination of specialized journals for the 'Europhysics Journal' label.

\section{Closing Remarks}

The President then recommended to Council that an Advisory Committee on Education should be set up by the Executive Committee, and this met with widespread approval. Before closing his report, the President announced the generous offer by E. H. S. Burhop to set up a fund so that, at each. EPS General Conference, there could be a lecture on the theme of physics and society. This would be known as the Cecil Powell Lecture, in honour of the work and the efforts of this eminent scientist to further co-operation amongst physicists froin all European countries.

\section{Divisions}

Representatives of Divisions outlined current activities and plans for 1973 , much as describc in Europhysics News, February 1973, pages 1-3. It was agreed that a pilot study and budget analysis should be carried out on the proposal to launch a Europhysics Conference Abstracts. 


\section{Financial affairs}

As mentioned in 'Viewpoint' in Europhysics News, April 1973, page 1, a state of emergency had to be declared within the European Physical Society. A task group was set up to report on the financial affairs and relevant administrative matters, in line with the proposal by L. A. A. Thomas.

\section{Executive Committee 1973/74}

The recommendations of the 1972/ 73 Executive Committee were accepted almost unanimously in an election in which there were no alternative candidates. It was thought desirable that a Russian physicist should replace L. A. Artsimovitch, and the delegation from the USSR were asked to submit a nominee for approval by Council. The Executive Committee for $1973 / 74$ will comprise :

\section{President : \\ H. B. G. Casimir \\ Vice-President : \\ Secretary : \\ N. Cindro \\ Vice-Secretary : \\ J. J. Went \\ Treasurer : \\ Vice-Treasurer : \\ Members : \\ T. Riste \\ O. S. Heavens \\ C. M. Braams \\ J. Friedel \\ K. Ganzhorn \\ G. Szigeti \\ I. Ursu}

\section{Increase in unit fee}

The President proposed that a decision to increase the unit fee should be prepared for the next meeting of the Council on 27 and 28 November 1973 , so that it could come into effect from the beginning of 1974 .

\section{Extra-curricular activities}

The solemn nature of the proceedings of the Council meeting was relieved by the excellent cuisine and the beautiful scenery in Romania. Also, the Romanian hosts offered a film show in which the attraction of the country for summer visitors and the variety of folk dancing and costumes were displayed. On another evening, there was a breathtaking show of Romanian folk dancing and a charming performance of folk music and singing.

The week's activities were completed by a one-day tour of the region which abounded in historically interesting monasteries and cathedrals. No doubt many delegates were encouraged by these glimpses of Romanian culture to consider returning to see more.

Alex H. Crawford

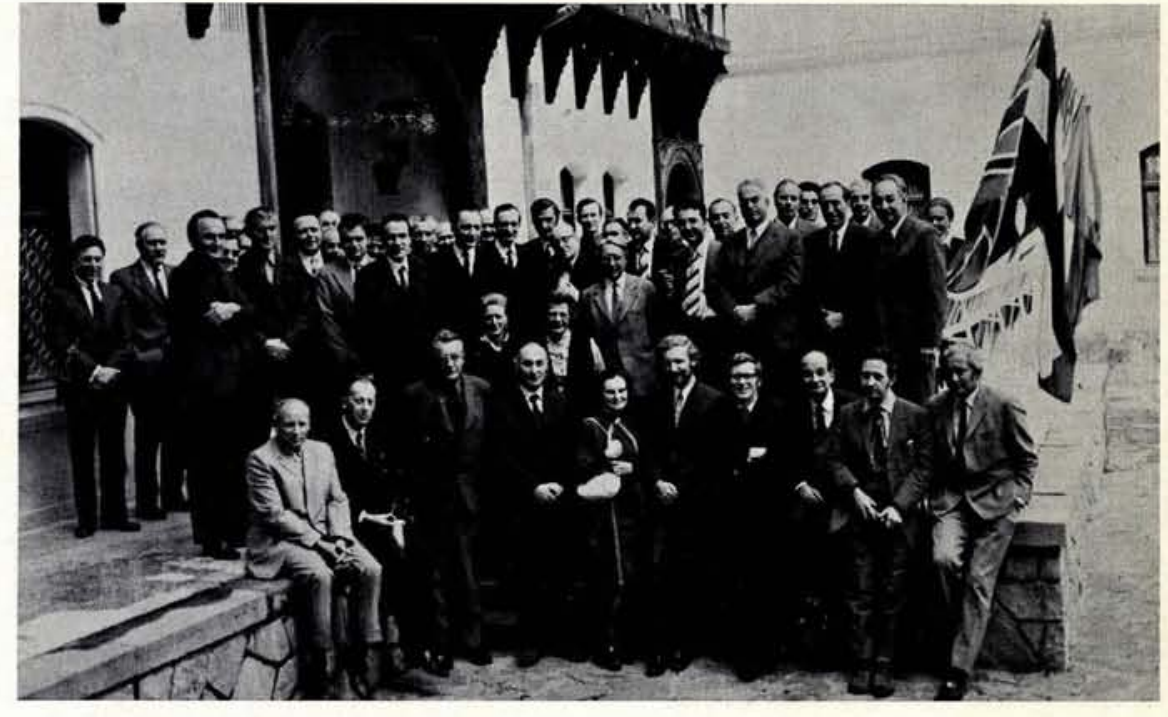

Delegates gather outside the former Summer Palace (now Hotel Sinaia-Peles) where the Spring Meeting of Council was held in Sinaia, Romania.

EUROPEAN SPACE RESEARCH ORGANISATION

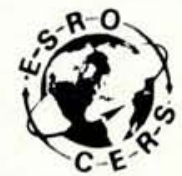

ORGANISATION EUROPEENNE DE RECHERCHES SPATIALES

\section{ESRO FELLOWSHIP PROGRAMME}

The Space Science Department can offer a few short term appoint ments to post graduate scientists in some of the following areas:

* MAgNETOSPHERIC PHYSICS - A physicist is required to assist in the analysis and theoretical interpretation of particle data now being obtained from the highly eccentric polar satellite HEOS-2.

* SPACE PLASMA PHYSICS. A physicist is required to continue studies connected with the development of satellite experiments for magnetospheric research using existing laboratory facilities.

* INFRA.RED ASTRONOMY - An I.R. astronomer, preferably with experience of airborne systems, is required to join in the develop ment and utilisation of a high resolution Michelson unit for airborne spectroscopy

* ADVANCED I.R. DETECTION SYSTEMS - Physicists with expe rience in I.R. heterodyne detection systems are required. They should be interested in the application of these techniques to I.R. astronomy.

* $\chi$ and $\gamma$-RAY ASTRONOMY A physicist is required for the development and analysis of instruments for $\chi$ and $\gamma$-ray astronomy. Experience in particle detection and measurement systems and a knowledge of computer utilisation and programming is necessary.

These appointments are for one to two years. Further information can be obtained from:

Head of Personnel

European Space Research and Technology Centre

Domeinweg 1 ,

Noordwijk, Holland. 